\title{
VINASSE FROM THE BRAZILIAN LIGNOCELLULOSIC ETHANOL PROCESS: CHEMICAL COMPOSITION AND POTENTIAL FOR BIOPROCESSES
}

\author{
VINHAÇA DO PROCESSO DE ETANOL LIGNOCELULÓSICO BRASILEIRO: \\ COMPOSIÇÃO QUÍMICA E POTENCIAL PARA BIOPROCESSOS \&
}

\author{
VINAZA DEL PROCESO DE ETANOL LIGNOCELULÓSICO BRASILEÑO: \\ COMPOSICIÓN QUIIMICA Y POTENCIAL PARA BIOPROCESOS ${ }^{\circ}$
}

Recebido em: 19/08/2020 - Aprovado em: 06/01/2021 - Publicado em: 20/04/2021

doi) http://dx.doi.org/10.18011/bioeng2021v15n1p42-68

Manuella Souza Silverio' (mso.silverio@gmail.com)

Rubens Perez Calegari² (rubenscalegari@usp.br)

Gabriela Maria Ferreira Lima Leite' ${ }^{1}$ (g.leite@usp.br)

Laysa Maciel Lewandowski Meira Prado1 (laysa.prado@yahoo.com.br)

Bianca Chaves Martins ${ }^{1}$ (martins.bianca92@gmail.com)

Eric Alberto da Silva ${ }^{1,3}$ (eric@eas.eng.br)

José Piotrovski Neto4 (jpiotrovski5@gmail.com)

André Gomig ${ }^{4}$ (eric@eas.eng.br)

Antonio Sampaio Baptista1 (asbaptis@usp.br)

1 University of São Paulo. College of Agriculture, Agroindustry, Food and Nutrition, Piracicaba, SP, Brazil.

2 University of São Paulo. Center of Nuclear Energy in Agriculture, Piracicaba, SP, Brazil.

${ }^{3}$ Nuclear and Energy Research Institute. Technology Center of Radiation, São Paulo, SP, Brazil.

${ }^{4}$ Engie Brasil. Florianópolis, SC - Brazil.

\section{ABSTRACT}

Brazil is the second-largest producer of ethanol and the alcoholic fermentation wastes have become a concern for both environmental and economic reasons. Recently, the Brazilian industry has implemented the second generation $(2 \mathrm{G})$ process to attend the growing for biofuel. In this study, we aimed to investigate whether the $2 G$ vinasse faces the same environmental challenges that first generation (1G) vinasses do, meaning vinasses from ethanol processes using sugarcane juice and/or molasses. Thus, vinasse was obtained from one of the recently-started 2G ethanol facilities in São Paulo State and then chemically characterized. Considering glycerol, mannitol, residual sugars, and organic acids concentrations altogether, it was determined that $2 \mathrm{G}$ vinasse had a total carbon source of $23,050 \mathrm{mg} \mathrm{L}-1$ (compared to $4,800 \mathrm{mg} \mathrm{L}-1$ in $1 \mathrm{G}$ vinasse). Magnesium, calcium, potassium, and others salts were determined as well. Based on its chemical composition, vinasses could be considered as nutrient sources for other bioprocesses. Finally, we brought some perspectives into bioprocesses with nutritional requirements that might be fully or partially provided by vinasses, leading to the production of bioenergy or bioproducts.

Keywords: Sucroenergetic sector. Chromatographic analyses. Waste valorization. Biorefinery. 2G vinasse. 


\section{INTRODUCTION}

The sucroenergetic sector plays a very important role in the Brazilian economy, accounting for about 2\% of the Brazilian Gross Domestic Product (UNICA, 2019a). Internationally, Brazil is an important player in ethanol production as the second-largest producer in the world. During the 2018/19 crop, Brazil produced 33 billion L of ethanol, and the largest ethanol producer, the United States, produced about 60 billion L in 2017 (UNICA, 2019b; U.S. ENERGY INFORMATION ADMINISTRATION, 2019). In this scenario, the Brazilian industry aims to more efficient processes so the growing demand for biofuels may be met.

According to recent studies on technical-economic evaluation, second generation (2G) ethanol processes have great potential in systems integrated with first-generation (1G) processes. Because $2 G$ ethanol production requires obtaining fermentable sugars from lignocellulosic feedstocks, different methods and operations are required, such as physicalchemical pretreatments and enzymatic hydrolysis, so production costs are higher when compared to $1 \mathrm{G}$ ethanol process (STEPHEN et al., 2012). Thus, a stand-alone $2 \mathrm{G}$ ethanol process might be more expensive than $1 \mathrm{G}$ processes. However, once they are integrated, $2 \mathrm{G}$ process provides a higher ratio of volumetric production per sugarcane ton. In addition to the optimization of facilities use, the integrated process becomes more attractive than specialized $1 G$ or 2 G production facilities (MACRELLI et al., 2014; DIAS et al., 2012).

Co-fermentation of hexoses and pentoses is still challenging for industrial scales. Therefore, integrated $1 G$ and $2 G$ processes might be configured as separate operations for $1 G$ and $2 G$ fermentations and a single distillation process, with a mixed $(1 G+2 G)$ fermented broth as input (MACRELLI et al., 2014).

Feedstocks, operations and process conditions have significant effects on industrial wastes composition. As for the $2 \mathrm{G}$ ethanol process, it requires different sugar sources and different operations by employing severe physical-chemical treatments and enzymatic hydrolysis on lignocellulosic feedstock to obtain fermentable sugars. Regarding ethanol from sugarcane, $2 \mathrm{G}$ ethanol process means using bagasse to obtain a sugar hydrolysate, rich in hexoses and pentoses. Though some undesired byproducts are commonly generated as well, such as organic acids, phenolic compounds, and furfuraldehydes (furfural and 5hydroxymethylfurfural). During alcoholic fermentation, these byproducts are not significantly consumed, therefore they might be found in vinasse (JARDINE et al., 2009). 
The $2 \mathrm{G}$ ethanol process is an emerging technology in the Brazilian industry and extensive research is needed so that effective treatment and management may be established for $2 \mathrm{G}$ organic wastes, based on their specific characteristics and composition.

Vinasse is the most important waste from alcoholic fermentation since it is generated at very large amounts: in the sugarcane $1 \mathrm{G}$ process, every $1 \mathrm{~L}$ of ethanol generates an average ratio of 10-15 L of vinasse (CORTEZ, 2010; ESPAÑA-GAMBOA et al., 2012; MORAES et al., 2015). For the $2 G$ ethanol process, there is no information for such a production ratio yet, although the undesired byproducts mentioned above might have inhibitory effects on fermentative microorganisms and the process might require diluted fermentation broths.

Vinasse fertirrigation became a common practice in Brazil during the $80 \mathrm{~s}$, when ethanol production had a fast increase because of government incentives. In the 1980/81 crop, Brazil produced 3.7 billion $L$ of ethanol and about 37 billion $L$ of vinasse. By the 1989/90 crop, Brazil produced 11.9 billion $L$ of ethanol and about 119 billion $L$ of vinasse, meaning an increase of over three times in less than ten years (UNICA, 2020).

Before the $80 \mathrm{~s}$, vinasses with no previous treatment were disposed of in rivers or other water bodies (RIBEIRO et al., 1983; SANTOS et al., 1981). Given the significant increase in vinasse generation during the 80 s, fertirrigation came up as an immediate and satisfactory alternative for an increasing volume of vinasse in such a short time.

Over the last forty years, the Brazilian industry has continuously increased the annual ethanol production, which also led to an increase of almost ten times in vinasse volume from the 1980/81 crop until 2018/19 crop. In the meantime, the Brazilian industry has kept the same practices regarding vinasse management from the 80 s until nowadays.

So, considering a process that employs severe physical-chemical treatments on lignocellulosic material, such as $2 \mathrm{G}$ ethanol process, would vinasse from such process bring even more risks of soil contamination once applied in fertirrigation? Would legislation based on potassium content be enough to regulate the safe amounts of $2 G$ vinasse for fertirrigation? Would there be any other applications for vinasses that could be safer for the environment, human health, and bring economic benefits as well?

In this study, we characterized the vinasse generated in one of the recently-started $2 G$ ethanol facilities in Brazil, which employs the integrated $1 G$ and $2 G$ process. By analyzing vinasse composition, we aimed to propose biotechnological applications that might lead to the production of important bioproducts and bioenergy. 


\section{MATERIALS AND METHODS}

\subsection{MATERIALS AND SAMPLES PREPARATION}

In this study, two types of vinasse were analyzed. A sample of vinasse from an ethanol process using sugarcane molasse (1G) was used as control for analyses. The $2 \mathrm{G}$ vinasse was obtained from an integrated production unit, $1 G+2 G$ ethanol process. Thus, in this study, we name $2 G$ vinasse the one composed of a mixture of $1 G$ and $2 G$ vinasses. Further details on the integrated process, such as $1 G$ and $2 G$ ratios, which operations are common to $1 \mathrm{G}$ and $2 \mathrm{G}$ processes or characteristics of fermentative microorganisms were not provided by the industry due to corporate and legal reasons related to patent deposit.

Both vinasses were obtained in a concentrated form from distilleries in São Paulo State, Brazil. Before analyses, they were both diluted to in natura concentrations: $1 \mathrm{G}$ vinasse, $3,2^{\circ} \mathrm{Bx} ; 2 \mathrm{G}$ vinasse, $3,8^{\circ} \mathrm{B} x$. Diluted vinasses were not submitted to any other pretreatments, except those required by the analytical methods described below. Samples were stored in $4^{\circ} \mathrm{C}$ and kept in room temperature before analyses.

\subsection{ANALYTICAL PROCEDURES}

\subsubsection{Chemical Oxygen Demand (COD)}

Vinasses were characterized using the colorimetric method (APHA, 2012). The following solutions were prepared: (i) 2.04\% K2Cr2O7 (m v-1), 3.33\% HgSO4 (m v-1) and $0.0167 \% \mathrm{H} 2 \mathrm{SO} 4$ ( $\mathrm{v} \mathrm{v}-1$ ) in distilled water; (ii) $1.012 \% \mathrm{Ag} 2 \mathrm{SO} 4(\mathrm{~m} \mathrm{v}-1)$ in concentrated $\mathrm{H} 2 \mathrm{SO}$. Reactions were prepared using $2.0 \mathrm{~mL}$ of diluted sample (1:50), $1.2 \mathrm{~mL}$ solution (i) and $2.8 \mathrm{~mL}$ solution (ii).

\subsubsection{Total Phenolic Compounds (TPC)}

We employed the procedure described by JULKUNEN-TIITO (1985). Samples were diluted 50 times to fit into the calibration curve.

\subsubsection{Organic acids and furfuraldehydes}

Organic acids, furfural, and 5-hydroxymethylfufural (HMF) were analyzed in a UFLC Prominence high-performance liquid chromatography system (SHIMADZU). 
For organic acids characterization, acetic acid, propionic acid, butyric acid, iso-butyric acid, and lactic acid were analyzed. The system consisted of Aminex HPX-87H (300 mm x $7.8 \mathrm{~mm}$; Bio-Rad) column, at $64^{\circ} \mathrm{C}$, eluted with $0.005 \mathrm{M} \mathrm{H} 2 \mathrm{SO} 4$ at a flow rate of $0.4 \mathrm{~mL}$ min-1, and a UV-Vis/DAD detector (208 nm). Samples were diluted 100 times, acidified with concentrated $\mathrm{H} 2 \mathrm{SO} 4$, until $\mathrm{pH} \leq 2.0$, as described elsewhere (PENTEADO et al., 2013), and filtered in $0.45 \mu \mathrm{m}$ cellulosic membranes. The volume sample was $100 \mu \mathrm{L}$.

The furfural and HMF analyses consisted of a system with a Shim-pack VP-ODS (5 $\mu \mathrm{m})$ of $250 \times 4.6 \mathrm{~mm}$ column, at $25^{\circ} \mathrm{C}$, eluted with acetonitrile and acetone $(1: 8 \mathrm{v} \mathrm{v-1)}$ in acetic acid (1\% v v-1), at a flow rate of $0.8 \mathrm{~mL} \mathrm{~min}-1$, and DAD detector (SHIMADZU SPDM20A) (275 nm). Samples were diluted 50 times, filtered in $0.45 \mu \mathrm{m}$ cellulosic membranes and analyzed in a volume of $20 \mu \mathrm{L}$.

\subsubsection{Carbohydrates, anions, and cations}

Glycerol, mannitol, sugars, cations, and anions were analyzed using ionic chromatographic systems (930 IC Compact, Metrohm). All samples were diluted 100 times, filtered in $0.45 \mu \mathrm{m}$ cellulosic membranes and analyzed with a sample volume of $20 \mu \mathrm{L}$.

Glycerol mannitol, sucrose, glucose, fructose, xylose, and arabinose were determined in ionic chromatographic system, using Metrosep Carb 1 150/4.0 column, at $30{ }^{\circ} \mathrm{C}$, eluted with $100 \mathrm{mM} \mathrm{NaOH}$ and $10 \mathrm{mM}$ Sodium acetate at a flow rate of $1.0 \mathrm{~mL} \mathrm{~min}-$ 1 and amperometric detector (METROHM, 2016).

Sodium, potassium, ammonium, iron, magnesium, and calcium were determined using the cation system in ionic chromatograph: Metrosep $C 4250 / 4.0$ column, at $30{ }^{\circ} \mathrm{C}$, eluted with $7.5 \mathrm{mM}$ tartaric acid, $0.135 \mathrm{mM}$ dipicolinic acid and $3.0 \mathrm{mM}$ ascorbic acid, at a flow rate of $0.9 \mathrm{~mL}$ min-1 and a conductivity detector (METROHM, 2015a).

Chloride, nitrate, nitrite, phosphate, and sulfate were determined in ionic chromatograph using the anion system: Metrosep A Supp 5 250/4.0, at $25^{\circ} \mathrm{C}$, eluted with $3.2 \mathrm{mM}$ Sodium carbonate and $1.0 \mathrm{mM}$ Sodium bicarbonate, at a flow rate of $0.7 \mathrm{~mL} \mathrm{~min}-1$ and a conductivity detector (METROHM, 2015b).

\subsubsection{Statistical analysis}

All analyses were carried out in triplicates. Calibration curves, descriptive statistical analyses of means and standard deviation were performed using Microsoft Excel $2010^{\circledR}$ software. 


\section{RESULTS AND DISCUSSION}

\subsection{VINASSES COMPOSITION: FEEDSTOCKS AND OPERATIONS INFLUENCE}

Table 1 details the chemical characterization for $1 G$ and $2 G$ vinasses. It also provides reference values, which were obtained from previous studies with $1 G$ vinasse characterization.

Table 1 - Physical-chemical characterization of $1 \mathrm{G}$ vinasse and $2 \mathrm{G}$ vinasses.

\begin{tabular}{|c|c|c|c|c|}
\hline$\left(\mathrm{mg} \mathrm{L}^{-1}\right)$ & 1G Vinasse & 2G Vinasse & Refe & ence \\
\hline $\mathrm{COD}\left(\mathrm{mgO}_{2} \mathrm{~L}^{-1}\right)$ & $26,715.19 \pm 161.49$ & $30,969.25 \pm 28.18$ & $21,000-33,600$ & $\begin{array}{c}\text { CORTEZ, 2010; } \\
\text { MORAES et al., } \\
2014\end{array}$ \\
\hline Sucrose & $285.50 \pm 16.02$ & $67.95 \pm 7.14$ & \multirow{7}{*}{$\begin{array}{l}\text { Total residual } \\
\text { sugars: } 962\end{array}$} & \multirow{7}{*}{$\begin{array}{l}\text { FERREIRA et } \\
\text { al., } 2011\end{array}$} \\
\hline Glucose & $88.78 \pm 8.91$ & $66.51 \pm 1.98$ & & \\
\hline Fructose & $130.71 \pm 13.05$ & $324.70 \pm 11.29$ & & \\
\hline Xylose & ND & $105.00 \pm 3.29$ & & \\
\hline Arabinose & ND & $12.16 \pm 0.78$ & & \\
\hline Furfural & ND & ND & & \\
\hline HMF & ND & ND & & \\
\hline Glycerol & $1,970.12 \pm 3.43$ & $701.28 \pm 2.10$ & 1,400 & $\begin{array}{l}\text { ORTIZ-MUNIZ } \\
\text { et al., } 2010\end{array}$ \\
\hline Lactic Acid & $571.27 \pm 14.21$ & $6,869.19 \pm 739.71$ & 7,740 & $\begin{array}{c}\text { DOWD et al., } \\
1994\end{array}$ \\
\hline Propionic Acid & ND & ND & & \\
\hline Iso-butyric Acid & ND & ND & & \\
\hline Butyric Acid & ND & $1,021.18 \pm 1,444.17$ & 325.61 & $\begin{array}{c}\text { PRADO et al., } \\
2016\end{array}$ \\
\hline Acetic Acid & $1,641.90 \pm 700.45$ & $13,844.38 \pm 4,189.51$ & 2,200 & $\begin{array}{c}\text { ESPAÑA- } \\
\text { GAMBOA et al., } \\
\text { 2012; DOWD et } \\
\text { al., } 1994\end{array}$ \\
\hline Mannitol & $130.41 \pm 1.50$ & $112.98 \pm 1.03$ & 89,00 & $\begin{array}{c}\text { DOWD et al., } \\
1994\end{array}$ \\
\hline TPC & $510.28 \pm 8.26$ & $2,407.21 \pm 21.17$ & 1,100 & $\begin{array}{c}\text { FERREIRA et } \\
\text { al., } 2011\end{array}$ \\
\hline
\end{tabular}




\begin{tabular}{|c|c|c|c|c|}
\hline Sulfate & $3,440.85 \pm 237.40$ & $2,467.17 \pm 29.54$ & $23.93-5,336$ & $\begin{array}{c}\text { ESPAÑA- } \\
\text { GAMBOA et al., } \\
\text { 2012; PRADO } \\
\text { et al., } 2016\end{array}$ \\
\hline Potassium & $8,746.78 \pm 526.10$ & $38,966.43 \pm 764.26$ & $600-13,000$ & $\begin{array}{c}\text { ESPAÑA- } \\
\text { GAMBOA et al., } \\
\text { 2012; MORAES } \\
\text { et al., 2015; } \\
\text { PATHAK et al., } \\
\text { 1999; BISWAS } \\
\text { et al., } 2009\end{array}$ \\
\hline Sodium & $4,959.23 \pm 236.05$ & $22,264.89 \pm 259.31$ & $50-31,300$ & $\begin{array}{l}\text { FERREIRA et } \\
\text { al., 2011; } \\
\text { PEDRO- } \\
\text { ESCHER et al., } \\
\text { 2014; COELHO } \\
\text { et al., } 2018\end{array}$ \\
\hline Calcium & $960.59 \pm 87.77$ & $6,850.61 \pm 347.12$ & $450-5,180$ & $\begin{array}{c}\text { ESPAÑA- } \\
\text { GAMBOA et al., } \\
\text { 2011; SOUZA } \\
\text { et al., } 2015\end{array}$ \\
\hline Magnesium & $1,739.63 \pm 420.63$ & $8,015.92 \pm 231.21$ & $420-520$ & $\begin{array}{l}\text { ESPAÑA- } \\
\text { GAMBOA et al., } \\
\text { 2011; COELHO } \\
\text { et al., } 2018\end{array}$ \\
\hline Phosphate & $109.52 \pm 0.61$ & ND & $1.3-3,796$ & $\begin{array}{c}\text { PEDRO- } \\
\text { ESCHER et al., } \\
\text { 2014; REIS et } \\
\text { al., } 2015\end{array}$ \\
\hline Nitrate & $513.74 \pm 0.54$ & $631.69 \pm 0.55$ & $1.3-17.6$ & $\begin{array}{c}\text { PEDRO- } \\
\text { ESCHER et al., } \\
2014 ; \\
\text { CASSMAN et } \\
\text { al., 2018; } \\
\text { SYDNEY, } 2013\end{array}$ \\
\hline Chloride & $1,546.98 \pm 5.08$ & $978.21 \pm 10.22$ & 3,500 & $\begin{array}{c}\text { NASPOLINI et } \\
\text { al., } 2017\end{array}$ \\
\hline Ammonium & ND & ND & & \\
\hline
\end{tabular}

ND: Not Detectable

Source: Original results.

COD in vinasses may vary between 21,000 and $33,600 \mathrm{mgO} 2 \mathrm{~L}-1$ and it is influenced by many factors, such as type of feedstocks and their quality (concerning microbial contamination), unit operations, process conditions and fermentative microorganisms' metabolism (CORTEZ, 2010; MORAES et al., 2015). COD content in both $1 \mathrm{G}$ and $2 \mathrm{G}$ 
vinasses were in accordance with previous studies, however, detailed chemical analysis revealed very different compositions.

Because lignin is the main source of phenolic compounds, detectable concentrations are not expected to be found in $1 \mathrm{G}$ vinasses, which are obtained from ethanol processes using sugarcane juice and/or molasses. In our study, TPC concentration in 2G vinasse was over four times higher than the concentration determined for $1 \mathrm{G}$ vinasse. Such a difference is clear evidence of how feedstock and operations from the ethanol processes might have an influence on vinasse composition.

The higher concentration we found in $2 G$ vinasse was expected because of the physical-chemical treatment used in sugarcane bagasse for the $2 \mathrm{G}$ ethanol process. Lignin is a very complex heterogeneous vegetable polymer, formed by several aromatic compounds. Once they are submitted to severe conditions, such as high temperature and pressure in physical-chemical treatments, several phenolic compounds may be released and eventually found in the hydrolysate. Since they are not significantly consumed during alcoholic fermentation, they are eventually found in vinasse (JARDINE et al., 2009).

As a less usual case for $1 \mathrm{G}$ vinasses, FERREIRA et al. (2011) reported 1,100 mg L- 1 of total phenolic compounds in $1 \mathrm{G}$ vinasse, almost twice higher than the concentration we determined for $1 \mathrm{G}$ vinasse in this study. That might be explained by the fact that some lignocellulosic parts, such as leaves and straw, are possibly processed during sugarcane milling for syrup production. During sugar production, syrup is submitted to very high temperatures and then molasse is obtained as a byproduct, which is further used as carbon source in alcoholic fermentation (SAHU, 2018). Such residual compounds are not supposed to be consumed during the fermentation process, so, as a result, they will be found in $1 \mathrm{G}$ vinasse.

Lactic acid concentration in $2 G$ vinasse was considerably higher than that determined in $1 \mathrm{G}$ vinasse. However, our results were consistent with the literature (DOWD et al., 1994), which reports that elevated lactic acid concentrations are common in industrial alcoholic fermentation since they are a bacterial contamination product.

Other organic acids may be indicators of bacterial contamination as well, such as propionic, iso-butyric, butyric, and acetic acids. Neither propionic acid nor iso-butyric acid was found in detectable concentration in any of vinasses. Butyric acid was determined only in $2 \mathrm{G}$ vinasse, in higher concentrations than those previously reported in the literature for $1 \mathrm{G}$ vinasses (PRADO et al., 2016). 
In comparison to the $1 \mathrm{G}$ vinasse we analyzed, and also previous reports in the literature, acetic acid concentration in $2 \mathrm{G}$ vinasse was notably higher (ESPAÑA-GAMBOA et al., 2012; DOWD et al., 1994).

In the $1 \mathrm{G}$ ethanol process, the acetic acid in fermented broths and vinasse results mostly from yeast metabolism and, possibly, from acetic bacteria metabolism as well, whenever there is contamination (LOPES et al., 2016).

In the $2 \mathrm{G}$ ethanol process, however, there might be acetic acid production from both yeasts and bacteria metabolisms, but the enzymatic treatment on sugarcane bagasse may be the main source. Enzymes are used to extract fermentable sugars from hemicellulose, which is a heterogeneous polymer composed by units of pentoses, hexoses, and acetyl groups. After acetyl groups are released into the fermentation broth, they are converted into acetic acid and they are not significantly consumed during alcoholic fermentation. As a result, high acetic acid concentrations might be found in $2 G$ vinasses (JARDINE et al., 2009). For these reasons, acetic acid concentration was indeed expected to be found in high concentration in the $2 G$ vinasse.

Furfural and HMF were expected to be found in $2 \mathrm{G}$ vinasse, since the $2 \mathrm{G}$ ethanol process may lead to sugars degradation due to high temperature and elevated pressure conditions in physical-chemical treatments. Furfural is formed from pentoses degradation and HMF results from hexoses degradation (JARDINE et al., 2009). However, our analyses found no detectable concentration of such compounds.

Residual sugars were detected in both vinasses. In $2 \mathrm{G}$ vinasse, xylose and arabinose were detected, as well as other residual sugars from alcoholic fermentation, such as sucrose, glucose, and fructose. Residual pentoses were expected to be found in $2 \mathrm{G}$ vinasse since $2 \mathrm{G}$ ethanol exploits both hexoses and pentoses from sugarcane bagasse.

Similarly, 1G vinasse was also characterized in residual hexoses. Total residual sugars concentrations were similar between vinasses in our study: $504.99 \mathrm{mg} \mathrm{L-1}$ in $1 \mathrm{G}$ vinasse and $576.32 \mathrm{mg} \mathrm{L-1}$ in $2 \mathrm{G}$ vinasse. Because sugars are exhausted in fermentation, very low concentrations of residual sugars are commonly detected in vinasses (FERREIRA et al., 2011).

Glycerol was determined in both vinasses and concentrations were consistent with previous studies (ORTIZ-MUNIZ et al., 2010). Glycerol is one of the main yeast metabolites in alcoholic fermentation since its metabolic pathway is related to redox balance maintenance and osmotic stress response (NEVOIGT \& STAHL, 1997). 
Mannitol, along with organic acids, is an indicator of bacterial contamination and the concentrations we determined for both $1 G$ and $2 G$ vinasses in our study were higher than those reported elsewhere (LOPES et al., 2016; EGGLESTON et al., 2007).

Vinasses usually have very high concentrations of sulfate due to many operations along the global process. During the sugar production process, sulphitation is applied for crystal sugar production. Thus, some residual forms of sulphur are generated in molasses and converted into sulphate, which will remain in the broth during alcoholic fermentation, and finally in vinasse (SAHU, 2018).

As for the ethanol production process, after alcoholic fermentation, it is common to apply $\mathrm{H}_{2} \mathrm{SO}_{4}$ on cream yeast, which is known as the acid treatment. The operation is useful to decrease bacterial contamination during inoculum recycling for the next fermentation batch (OLIVA-NETO \& YOKOYA, 2001). Acid treatment may also generate residual forms of sulphur, such as sulphate, which are eventually found in vinasse. Still, some authors suggest $\mathrm{H}_{2} \mathrm{SO}_{4}$ to be used in physical-chemical pre-treatments on sugarcane bagasse for $2 G$ ethanol process (JARDINE et al., 2009), which could be yet another possible source of sulfates in $2 G$ vinasses. However, this type of information was not confirmed by the industry that provided the $2 \mathrm{G}$ vinasse for this study. Sulfate concentrations from our analyses were consistent with those in literature for $1 G$ vinasses (ESPAÑA-GAMBOA et al., 2012; PRADO et al., 2016).

In our study, nitrate was determined in higher concentrations than those found in literature, for both $1 G$ and $2 G$ vinasses (PRADO et al., 2016; PEDRO-ESCHER et al., 2014; CASSMAN et al., 2018; SYDNEY, 2013). Ammonium was investigated and no detectable concentration was found for neither vinasses.

Other components, such as salts of sodium, calcium, magnesium, chloride, and potassium were determined in important concentrations. These salts have been previously reported by other authors with highly variable concentrations in $1 \mathrm{G}$ vinasses. In our analyses, $2 G$ vinasse had higher concentrations for calcium and magnesium salts than those reported elsewhere, for $1 G$ vinasses. Sodium and chloride concentrations in $2 G$ vinasse were following other authors' results with $1 G$ vinasse samples. As for our analysis with $1 \mathrm{G}$ vinasse, concentrations of sodium, calcium, chloride, and phosphate salts were consistent with those reported elsewhere. No detectable concentration for phosphate was determined in 2G vinasse (COELHO et al., 2018; PEDRO-ESCHER et al., 2014; FERREIRA 
et al., 2011; ESPAÑA-GAMBOA et al., 2012; SOUZA et al., 2015; REIS et al., 2015; NASPOLINI et al., 2017).

Potassium content in vinasses is commonly very high, ranging from 600 to 13,000 mg L-1 (ESPAÑA-GAMBOA et al., 2012; MORAES et al., 2015; PATHAK et al., 1999; BISWAS et al., 2009). In our analyses, potassium content in $1 \mathrm{G}$ vinasse was consistent with those found by other authors, whereas potassium content in $2 \mathrm{G}$ vinasse was highly above that range.

São Paulo State accounts for the most important share of ethanol production in Brazil and is the only region in the country where vinasse fertirrigation must follow a governmental technical regulation. Since potassium salts are usually the most abundant in vinasses, its concentration should be considered for vinasse application in soil in order to avoid nutrients imbalance and salinization (CETESB, 2013).

In this regard, $2 \mathrm{G}$ vinasse management could be an even greater challenge if fertirrigation is to be considered. According to the São Paulo regulation, lower volumes of $2 \mathrm{G}$ vinasse would be allowed per area, which means transporting vinasse to further fields. Costs with fuel for trucks, labor and specialized material for vinasse storage and transportation (by trucks, channels or lagoons) are implicated.

Considering fertirrigation, $2 \mathrm{G}$ vinasse might be economically very challenging. Moreover, calcium, sodium, magnesium salts, and organic acids were found in very high concentrations as well. So, not only from the economic point of view but also for environmental concerns, $2 \mathrm{G}$ vinasse might arise the urgent need for alternative and more innovative technologies in its management strategies.

\subsection{VINASSE MANAGEMENT CHALLENGES: ADVANTAGES, DISADVANTAGES OF FERTIRRIGATION AND OTHER TECHNOLOGICAL OPPORTUNITIES}

Vinasses might have a variable composition, but in general, they are interesting sources of salts, carbon (organic acids and glycerol), other nutrients, and even water. In Brazil vinasse fertirrigation is an important supply of these nutrients for sugarcane fields. Moreover, previous studies have showed that vinasse fertirrigation might indeed promote higher sugar production by increasing the sugarcane growth and rooting (MEDINA et al., 2002; PAULINO et al., 2002). 
An important factor about vinasse fertirrigation is that it means a low-cost investment, with low-cost maintenance, as well. The use of vinasse in sugarcane fields demands facilities such as piping, pumps, channels, trucks, and storage lagoons. The nutrients recycling by fertirrigation also means purchasing less fertilizers for sugarcane crops (CHRISTOFOLETTI et al., 2013).

In the last years many studies have been focusing on the impacts that fertirrigation might have on the quality of soil and groundwaters.

According to literature, the continuous vinasse fertirrigation in a certain area means the continuous addition of specific nutrients, such as salts and organic acids, which might lead to an unbalanced composition of nutrients in the soil (SILVA et al., 2007; OLIVEIRA et al., 2015; PEDRO-ESCHER et al., 2014).

Researchers reported that soil physical structure might be altered as a consequence of such chemical imbalance. The result is that fertirrigated areas will eventually be salinized and potassium, sulfate, nitrate, and metals might be leached through soil inner layers and contaminate superficial and groundwaters (SILVA et al., 2007; CASSMAN et al., 2018; CHRISTOFOLETTI et al., 2013).

SOTO et al. (2015) suggested that, depending on environmental conditions, soil, and vinasse characteristics, vinasse percolation might occur between one to three years after fertirrigation.

Salts have usually been the greatest concern in vinasse composition because of their potentially negative effects on soil salinization. However, recent studies have quantified greenhouse gases (GHG) emissions from vinasse fertirrigated areas. The results indicated that emissions are significant and environmental concern with vinasse should be wider than soil degradation (OLIVEIRA et al., 2015; CASSMAN et al., 2018).

Considering all these aspects, 2G vinasse might bring the same environmental concerns. As determined in our study, 2G vinasse presented as many salts and organic acids as $1 \mathrm{G}$ vinasse, or more. In our analyses, 2G vinasse had higher concentrations of potassium, sodium, nitrate, lactic acid, acetic acid, butyric acid, and TPC than those determined in $1 \mathrm{G}$ vinasse. Further studies with $2 \mathrm{G}$ are definitely needed, considering that more vinasses from different locations and processes should be analyzed. However, our results have already indicated that $2 G$ vinasse might bring the same environmental problems known to be related to $1 \mathrm{G}$ vinasse. 
There is great interest in continuing with vinasse fertirrigation because nutrients from sugarcane can be recycled to crops and have positive effects on sugarcane growth. Given the advantages of vinasse fertirrigation, more sustainable management could start by employing the biodigested vinasse.

MORAES et al. (2017) have compared the GHG emissions during the transportation of in natura and biodigested vinasses for fertirrigation. Their results showed that biodigested vinasse did not show any detectable $\mathrm{CH} 4$ emissions. As for $\mathrm{N} 2 \mathrm{O}$ emissions, they observed a decrease of about $48 \%$ to $78 \%$ in comparison to in natura vinasse.

The biodigested vinasse means the product of anaerobic digestion (AD), which is the bioprocess that consumes dissolved carbon compounds, converting them into biogas. The main product of $A D$ is the biomethane, which can be further purified and used in energy generation. Still, in an ethanol distillery scenario, the biodigested wastewater would also have an important role as a fertilizer, since potassium, magnesium, calcium, and other salts are not significantly removed during biogas production (BARROS et al., 2017; LÓPEZLÓPEZ et al., 2015).

Fertirrigation and biogas production have important features that make them very interesting alternatives for vinasse management in the Brazilian industry. However, vinasse is generated in very large volumes and, despite $A D$ being a very efficient and wellestablished technology, multiple strategies are needed.

$A D$ with concentrated vinasses has been previously investigated as a more efficient alternative for vinasses (NACHEVA et al., 2009). And recently, many studies have been expanding knowledge about wastewaters' valorization. For that reason, many residues from different processes have been studied as potential culture media components. Among those, dairy effluents, molasses, paper mill effluents, winery wastewaters, food processing wastes, whey thin stillage, crude glycerol, and many others have been investigated (RATHIKA et al., 2018; KADIER et al., 2014; REVIN et al., 2018; SANTOS et al., 2016).

Table 2 provides some information from studies in which agroindustrial wastes, including sugarcane vinasse $(1 \mathrm{G})$, were evaluated as a component of culture medium for biofuel or bioproducts synthesis.

These bioprocesses employ bacteria or a consortium of microorganisms. In Table 2 there are bioprocesses with Pseudomonas spp. and Bacillus spp., for biosurfactant production (NASPOLINI et al., 2017; MD, 2012), Xanthomonas campestris for xanthan gum production (non-food applications) (BECKER et al., 1998), Bacillus spp. for bioplastic 


\section{Manuella Souza Silverio et al.}

production (RATHIKA et al., 2018; DESOUKY et al., 2017), Acetobacter spp. and Gluconacetobacter spp. for bacterial cellulose (BC) production (REVIN et al., 2018; ESA et al., 2014) and Corynebacterium glutamicum for amino acids production (animal feed) (BECKER et al., 2011). These species are able to consume saccharides, but glycerol and organic acids as well, making them potentially suitable for growth and biosynthesis in vinasse.

Some bioprocesses in Table 2 are already well-established in the industry, as AD, xanthan gum, and amino acids production. Other bioprocesses, such as biosurfactants, bioplastics, BC production, and microbial electrolysis cell (MCE) are not yet well-established in large scales, so they are majorly in early stages and/or scaling up to pilot scale studies. 
Vinasse from the brazilian lignocellulosic ethanol process: chemical composition and ...

Table 2. Bioprocesses, nutrient requirement, products and application.

\begin{tabular}{|c|c|c|c|c|c|c|c|c|}
\hline Bioprocess & $\begin{array}{c}\text { Nutrient } \\
\text { requirements for } \\
\text { culture medium }\end{array}$ & Product & $\begin{array}{l}\text { Product's } \\
\text { applications }\end{array}$ & $\begin{array}{l}\text { Current state of } \\
\text { technology } \\
\text { development }\end{array}$ & $\begin{array}{c}\text { Does it need } \\
\text { supplementation? }\end{array}$ & $\begin{array}{l}\text { Complex } \\
\text { substrates } \\
\text { previously } \\
\text { tested }\end{array}$ & $\begin{array}{l}\text { Challenges in } \\
\text { using vinasse }\end{array}$ & References \\
\hline $\begin{array}{l}\text { Anaerobic } \\
\text { digestion }\end{array}$ & $\begin{array}{l}\text { COD } 12,100- \\
44,500 \mathrm{mgO}_{2} \mathrm{~L}^{-} \\
1 ; \quad \text { Potassium } \\
\left(0.149-7.2 \mathrm{~g} \mathrm{~L}^{-}\right. \\
\left.{ }^{1}\right), \quad \text { Calcium } \\
\left(0.005-0.32 \mathrm{~g} \mathrm{~L}^{-}\right. \\
\left.{ }^{1}\right) ; \text { Sodium }(0.16 \\
\left.\mathrm{g} \mathrm{L}^{-1}\right) ; \text { sulfate } \\
\left(1.0-5.336 \mathrm{~g} \mathrm{~L}^{-}\right. \\
1) ; \text { phosphates } \\
\left(0.141 \mathrm{~g} \mathrm{~L}^{-1}\right) ; \\
\text { Magnesium } \\
\left(0.18 \mathrm{~g} \quad \mathrm{~L}^{-1}\right) \\
\text { acetic acid } \\
\left(2.237 \mathrm{~g} \quad \mathrm{~L}^{-1}\right) ; \\
\text { propionic acid } \\
\left(4.3 \mathrm{~g} \mathrm{~L}^{-1}\right)\end{array}$ & $\mathrm{CH}_{4}$ & Biofuel & $\begin{array}{l}\text { Well } \\
\text { established in } \\
\text { industry }\end{array}$ & No & $\begin{array}{l}\text { Sugarcane } \\
\text { vinasse, tequila } \\
\text { vinasse, swine } \\
\text { wastewater, } \\
\text { domestic } \\
\text { wastewater }\end{array}$ & $\begin{array}{l}\text { High sulfate } \\
\text { concentrations } \\
\text { might lead to } \\
\mathrm{H}_{2} \mathrm{~S} \text { production, } \\
\text { which is a } \\
\text { corrosive gas }\end{array}$ & $\begin{array}{l}\text { ESPAÑA-GAMBOA et } \\
\text { al., 2012; BARROS et } \\
\text { al., 2017; LÓPEZ- } \\
\text { LÓPEZ et al., } 2015\end{array}$ \\
\hline $\begin{array}{l}\text { Biosurfactant } \\
\text { production }\end{array}$ & 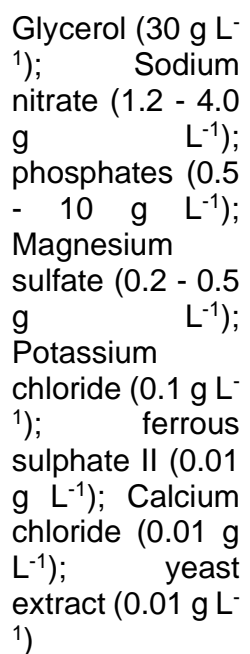 & $\begin{array}{l}\text { Glycolipids } \\
\text { rhamnolipids }\end{array}$ & $\begin{array}{l}\text { Mobilizing agent } \\
\text { in agriculture; } \\
\text { detergent; } \\
\text { antimicrobial; } \\
\text { biopesticide; } \\
\text { applied in crude } \\
\text { oil and } \\
\text { hydrocarbons } \\
\text { degradation }\end{array}$ & $\begin{array}{l}\text { Laboratory } \\
\text { scale }\end{array}$ & $\begin{array}{l}\text { Glycerol or other } \\
\text { carbon source } \\
\text { supplementation; } \\
\text { phosphates; trace } \\
\text { elements, such as } \\
\text { B, Cu, Mn, Mo, Zn }\end{array}$ & $\begin{array}{l}\text { Sugarcane } \\
\text { vinasse, } \\
\text { molasses, } \\
\text { crude oils, corn } \\
\text { steep liquor }\end{array}$ & $\begin{array}{l}\text { Studies on } \\
\text { standardization } \\
\text { of vinasse } \\
\text { application are } \\
\text { still required }\end{array}$ & $\begin{array}{l}\text { NASPOLINI et al., } \\
\text { 2017; BECKER et al., } \\
\text { 1998; BENINCASA et } \\
\text { al., } 2002\end{array}$ \\
\hline
\end{tabular}

BIOENG, v. 15, n. 1, p. 42-68, 2021. DOI: http://dx.doi.org/10.18011/bioeng2021v15n1p42-68 


\begin{tabular}{|c|c|c|c|c|c|c|c|c|}
\hline $\begin{array}{l}\text { Xanthan gum } \\
\text { production }\end{array}$ & $\begin{array}{l}\text { Sucrose or } \\
\text { glycerol }\left(20 \mathrm{~g} \mathrm{~L}^{-}\right. \\
1) ; \text { urea }\left(0.1 \mathrm{~g} \mathrm{~L}^{-}\right. \\
1) ; \text { phosphates } \\
\left(1-3 \mathrm{~g} \mathrm{~L}^{-1}\right) ; \\
\text { yeast extract }(3 \\
\left.\mathrm{g} \mathrm{\textrm {L } ^ { - 1 }}\right) ; \text { sulphate } \\
\text { ammonium }(1.5 \\
\mathrm{g} \quad \mathrm{L}-1) \text {; } \\
\text { Magnesium } \\
\text { sulphate }(0.3 \mathrm{~g} \\
\left.\mathrm{L}^{-1}\right)\end{array}$ & Acidic polysaccharide & $\begin{array}{l}\text { Thickener and } \\
\text { emulsifier for } \\
\text { food, oil, } \\
\text { pharmaceutical, } \\
\text { cosmetic, paper, } \\
\text { paint and textile } \\
\text { industries; and } \\
\text { gelling a } \\
\text { suspending } \\
\text { agent }\end{array}$ & $\begin{array}{l}\text { Well } \\
\text { established } \\
\text { industry }\end{array}$ & $\begin{array}{l}\text { Carbon (sucrose or } \\
\text { glycerol) and } \\
\text { nitrogen (urea or } \\
\text { yeast extract); }\end{array}$ & $\begin{array}{l}\text { Sugarcane } \\
\text { molasse; } \\
\text { glycerin; stach } \\
\text { hydrolysates; } \\
\text { green coconut } \\
\text { shell } \\
\text { hydrolysate; } \\
\text { straw } \\
\text { hydrolysate }\end{array}$ & $\begin{array}{l}\text { In industry, } \\
\text { xanthan gum is } \\
\text { produced from } \\
\text { sugarcane } \\
\text { juices or } \\
\text { molasses, which } \\
\text { have a very } \\
\text { similar } \\
\text { composition in } \\
\text { comparison to } \\
\text { sugarcane } \\
\text { vinasse, except } \\
\text { for the carbon } \\
\text { source } \\
\text { composition. } \\
\text { Using vinasse } \\
\text { could decrease } \\
\text { production costs }\end{array}$ & $\begin{array}{l}\text { SANTOS et al., 2016; } \\
\text { BECKER et al., 1998; } \\
\text { BRANDÃO et al., 2013; } \\
\text { RONCEVIC et al., 2014 }\end{array}$ \\
\hline $\begin{array}{l}\text { Bioplastic } \\
\text { production }\end{array}$ & 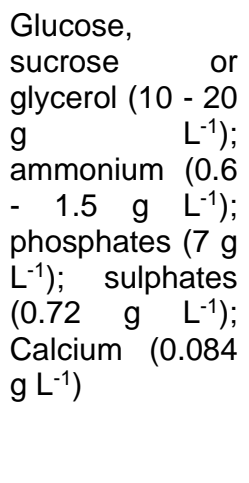 & Polyhydroxyalkanoates & $\begin{array}{l}\text { Packaging, } \\
\text { moulded goods, } \\
\text { coatings, } \\
\text { adhesives, films }\end{array}$ & $\begin{array}{l}\text { Mainly } \\
\text { laboratory and } \\
\text { pilot scale, still } \\
\text { emerging in } \\
\text { industry }\end{array}$ & $\begin{array}{lr}\text { Carbon } & \text { source } \\
\text { (sucrose } & \text { or } \\
\text { glycerol); nitrogen } \\
\text { source } \\
\text { (ammonium); } \\
\text { phosphates }\end{array}$ & $\begin{array}{l}\text { Sugarcane } \\
\text { molasse; } \\
\text { cheese whey; } \\
\text { wheat bran; } \\
\text { paper mill } \\
\text { effluent; dairy } \\
\text { whey }\end{array}$ & $\begin{array}{l}\text { Studies have } \\
\text { already } \\
\text { evaluated } \\
\text { sugarcane } \\
\text { molasse, which } \\
\text { is a substrate } \\
\text { with similar } \\
\text { composition in } \\
\text { comparison to } \\
\text { vinasse, except } \\
\text { for the carbon } \\
\text { source } \\
\text { composition. }\end{array}$ & $\begin{array}{l}\text { RATHIKA et al., 2018; } \\
\text { DESOUKY et al., 2017; } \\
\text { KHIYAMI et al., } 2011\end{array}$ \\
\hline $\begin{array}{l}\text { Bacterial } \\
\text { cellulose }\end{array}$ & $\begin{array}{l}\text { Glycerol (2.39- } \\
\left.7,87 \mathrm{~g} \mathrm{~L}^{-1}\right) ; \text { lactic } \\
\text { acid }(5.07-7.41 \\
\left.\mathrm{g} \mathrm{L}^{-1}\right) ; \text { acetic } \\
\text { acid }(0.56-2.72 \\
\left.\mathrm{g} \mathrm{L}^{-1}\right) ; \text { succinic }\end{array}$ & Cellulose & $\begin{array}{l}\text { Food packaging; } \\
\text { reinforcement } \\
\text { material for } \\
\text { electronic and } \\
\text { biomedical } \\
\text { materials; paper } \\
\text { restoration }\end{array}$ & $\begin{array}{l}\text { Laboratory } \\
\text { scale }\end{array}$ & $\begin{array}{l}\text { Nitrogen sources } \\
\text { might be required. }\end{array}$ & $\begin{array}{l}\text { Wheat thin } \\
\text { stillage; cheese } \\
\text { whey; waste } \\
\text { beer yeast; } \\
\text { grape skin; oil } \\
\text { mill residue }\end{array}$ & $\begin{array}{l}\text { Studies on } \\
\text { stardadization of } \\
\text { vinasse use are } \\
\text { still required; } \\
\text { using vinasse } \\
\text { could decrease }\end{array}$ & $\begin{array}{l}\text { REVIN et al., } 2018 ; \text { ESA } \\
\text { et al., } \quad 2014 ; \\
\text { RATANAPARIYANUCH } \\
\text { et al., } 2011\end{array}$ \\
\hline
\end{tabular}

(EIOENG, v. 15, n. 1, p. 42-68, 2021. DOI: http://dx.doi.org/10.18011/bioeng2021v15n1p42-68 
Vinasse from the brazilian lignocellulosic ethanol process: chemical composition and ...

\begin{tabular}{|c|c|c|c|c|c|c|c|c|c|}
\hline & $\begin{array}{l}\text { acid }(0.63-0.93 \\
\left.\mathrm{g} \mathrm{L}^{-1}\right)\end{array}$ & & & & & & & $\begin{array}{l}\text { production } \\
\text { costs. }\end{array}$ & \\
\hline Amino acids & 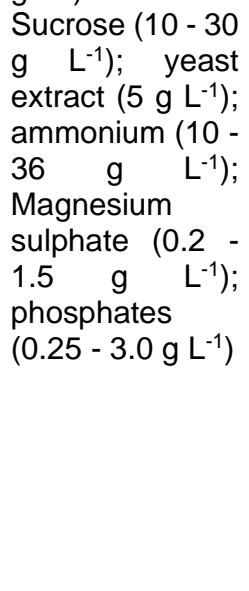 & $\begin{array}{l}\text { Lysine, } \\
\text { tryptophan }\end{array}$ & threonine, & $\begin{array}{l}\text { Animal feed } \\
\text { supplementation }\end{array}$ & $\begin{array}{l}\text { Well stablished } \\
\text { in industry }\end{array}$ & $\begin{array}{l}\text { Carbon (sucrose), } \\
\text { nitrogen } \\
\text { (ammonium) } \\
\text { sources; } \\
\text { phosphates }\end{array}$ & $\begin{array}{l}\text { Sugarcane, } \\
\text { beet molasses; } \\
\text { starch } \\
\text { hydrolysates }\end{array}$ & $\begin{array}{l}\text { Amino acids } \\
\text { production with } \\
\text { complex culture } \\
\text { media is well } \\
\text { established, } \\
\text { including } \\
\text { sugarcane } \\
\text { molasses, which } \\
\text { have a similar } \\
\text { composition in } \\
\text { comparison to } \\
\text { sugarcane } \\
\text { vinasse, except } \\
\text { for the carbon } \\
\text { source } \\
\text { composition. }\end{array}$ & $\begin{array}{l}\text { BECKER et al., 2011; } \\
\text { YING et al., 2014; LIU et } \\
\text { al., } 2016\end{array}$ \\
\hline $\begin{array}{l}\text { Microbial } \\
\text { electrolysis cells } \\
\text { (MEC) }\end{array}$ & $\begin{array}{l}\mathrm{COD} \quad 6,500 \\
\mathrm{mgO}_{2} \\
\text { residual } \\
\text { reducing sugars } \\
\left(0.2 \mathrm{~g} \mathrm{~L}^{-1}\right) ; \text { acetic } \\
\text { acid }\left(0.74 \mathrm{~g} \mathrm{~L}^{-1}\right) ; \\
\text { propionic acid } \\
\left(0.35 \text { g } \mathrm{L}^{-1}\right) ; \\
\text { butyric acid }(0.2 \\
\left.\mathrm{g} \mathrm{L}^{-1}\right)\end{array}$ & $\mathrm{H}_{2}$ & & Biofuel & $\begin{array}{l}\text { Laboratory } \\
\text { scale }\end{array}$ & No & $\begin{array}{l}\text { Lignocellulosic } \\
\text { biomass } \\
\text { wastes; } \\
\text { molasses; } \\
\text { domestic } \\
\text { wastewater; } \\
\text { fermentation } \\
\text { effluents in } \\
\text { general; food } \\
\text { processing } \\
\text { wastewaters }\end{array}$ & $\begin{array}{l}\text { MEC is a } \\
\text { recently } \\
\text { developed } \\
\text { technology and } \\
\text { it is not yet ready } \\
\text { for large scale } \\
\text { implementation. } \\
\text { Most studies still } \\
\text { focus on higher } \\
\text { yields, suitable } \\
\text { material for } \\
\text { electrodes, and } \\
\text { costs } \\
\text { substrates } \\
\text { optimization in } \\
\text { general. }\end{array}$ & $\begin{array}{l}\text { LU et al., 2009; KADIER } \\
\text { et al., } 2014\end{array}$ \\
\hline
\end{tabular}


Regardless of the current state of technology development, vinasses have potential as nutrient sources for biofuels and bioproducts generation, providing a wider view for vinasse application.

Although many factors contribute to the exact determination of culture medium composition for a specific bioprocess, such as the microorganism strain, bioproduct characteristics, biosynthesis conditions, downstream operations, and others, some general information about the main microbial nutrient requirements are presented (Table 2).

As mentioned above, the employed bacteria are capable of consuming different types of carbon sources. Glycerol might be the chosen carbon source for biosurfactant, xanthan gum, and BC production. Despite not being well established, amino acid production by Corynebacterium glutamicum is also possible through glycerol consumption by engineering strains for that purpose (RITTMANN et al., 2008). Besides, organic acids found in vinasse might be important carbon sources in $B C$ and MCE processes. As for $A D$, the bioprocess is carried out by a consortium of microorganisms, involving many bacterial and archea species, which consume a wide variety of carbohydrates and organic acids, especially acetic acid (STAMS, 1994).

The vinasses we characterized in our study had an important carbon concentration considering glycerol, mannitol, residual sugars, and organic acids altogether. For $1 \mathrm{G}$ vinasse, we determined over $4,800 \mathrm{mg} \mathrm{L}-1$ of carbon sources, and for $2 \mathrm{G}$ vinasse, over $23,050 \mathrm{mg} \mathrm{L}-1$. Thus, both vinasses, but most importantly $2 \mathrm{G}$ vinasse, have interesting carbon sources concentrations to be exploited, meaning energetic resources to be seized by industrial microorganisms.

For all the bioprocesses listed in Table 2, there are possible challenges in applying vinasse. High sulfate concentrations $(A D)$, the lack of studies on the specific usage of vinasse as substrate (xanthan gum, bioplastic, BC and amino acids production), replacing the use of sugarcane molasse by sugarcane vinasse (biosurfactant, xanthan gum, bioplastic, and amino acids) or the technological development itself (MCE). On the other hand, all these bioprocesses have been extensively studied with complex components for culture media, including some agro-industrial wastes.

Finally, taking into consideration the biorefinery concept, the use of vinasse in other bioprocesses could also mean water recycling. Different from for water treatment technologies that employ resins and membranes, with high investment and maintenance 
costs, keeping vinasse inside a production facility and employing it in the production of bioproducts could optimize logistics and resources use.

Expanding studies on vinasse application in bioprocesses could turn a wastewater, with high pollutant potential, into a nutrient source for processes with economic and environmental benefits.

\section{CONCLUSIONS}

Some typical compounds obtained from lignocellulosic physical-chemical and enzymatic pretreatments were found at very high concentrations in $2 \mathrm{G}$ vinasse, namely acetic acid, and total phenolic compounds.

Contents of potassium, sodium, calcium, magnesium, nitrate, sulfate, and other organic acids were higher than those we determined for $1 \mathrm{G}$ vinasse. These compounds might bring risks to the environment once vinasse is commonly employed in fertirrigation. Therefore, 2G vinasse might bring the same risks for soil acidification and leaching.

However, these same compounds are needed in other bioprocesses. That makes both $1 \mathrm{G}$ and $2 \mathrm{G}$ vinasses interesting materials as a potential source of nutrients for biotechnological applications.

\section{REFERENCES}

APHA. "Standard Methods for the Examination of Water and Wastewater: 5220 D. Closed Reflux, Colorimetric Method", edited by American Public Health Association, pp. 5-14 - 519, 2012. ISBN 978-0875530130.

Barros, V. G.; Duda, R. M.; Vantini, J. S.; Omori, W. P.; Ferro, M. T.; Oliveira, R. A. Improved methane production from sugarcane vinasse with filter cake in thermophilic UASB reactors, with predominance of Methanothermobacter and Methanosarcina archaea and Thermotogae bacteria. Bioresource Technology, v. 244: 371-381, 2017. DOI: 10.1016/j.biortech.2017.07.106.

Becker, A.; Katzen, F.; Puhler, A.; lelpi, L. Xanthan gum biosynthesis and application: a biochemical/genetic perspective. Applied Microbiology Biotechnology, v. 50: 145-152, 1998. 
Becker, J.; Zelder, O.; Hafner, S.; Schroder, H.; Wittmann, C. From zero to hero - Designbased systems metabolic engineering of Corynebacterium glutamicum for L-lysine production. Metabolic Engineering, v. 13:159-168, 2011. DOI:

10.1016/j.ymben.2011.01.003.

Benincasa, M.; Contiero, J.; Manresa, M. A.; Moraes, I. O. Rhamnolipid production by Pseudomonas aeruginosa LBI growing on a slapstick as the sole carbon source. Journal of Food Engineering, v. 54: 283-288, 2002. DOI: 10.1016/S0260-8774(01)00214-X.

Biswas, A. K.; Mohanty, M.; Hati, K. M.; Misra, A. K. Distillery effluents effect on soil organic carbon and aggregate stability of a Vertisol in India. Soil \& Tillage Research, v. 104: 241-246, 2009. DOI: 10.1016/j.still.2009.02.012.

Brandão, L. V.; Assis, D. J.; López, J. A.; Espiridião, M. C. A.; Echevarria, E. M.; Druzian, J. I. Bioconversion from crude glycerin by Xanthomonas campestris 2103: xanthan production and characterization. Brazilian Journal of Chemical Engineering, v. 30: 737746, 2013. DOI: 10.1590/S0104-66322013000400006.

Cassman, N. A.; Lourenço, K. S.; Carmo, J. B.; Cantarella, H.; Kuramae, E. E. Genomeresolved metagenomics of sugarcane vinasse bacteria. Bioenergy for Biofuels, v. 11: 48, 2018. DOI: 10.1186/s13068-018-1036-9.

CETESB. Norma Técnica P4.231, 3aㅡ Edição, 2ª Versão: Vinhaça - critérios e procedimentos para aplicação no solo. Access: https://cetesb.sp.gov.br/wpcontent/uploads/2013/11/NTC-P4.231_Vinhaça_-Critérios-e-procedimentos-paraaplicação-no-solo-agr\%C3\%ADcola-3⿳亠丷⿵冂-Ed-2ª-VERSÃO.pdf, 2013.

Christofoletti, C. A.; Pedro-Escher, J.; Correia, J. E.; Marinho, J. F. U.; Fontanetti, C. S. Sugarcane vinasse: Environmental implications of its use. Waste Management, v. 33: 2752-2761, 2013. DOI: 10.1016/j.wasman.2013.09.005.

Coelho, M. P. M.; Correia, J. E.; Vasques, L. I.; Marcato, A. C. C.; Guedes, T. A.; Soto, M. A.; Basso, J. B.; Kiang. C.; Fontanetti, C. S. Toxicity evaluation of leached of sugarcane vinasse: Histopathology and immunostaining of cellular stress protein. Ecology and Environmental Safety, v. 165: 367-375, 2018. DOI: 10.1016/j.ecoenv.2018.08.099.

Cortez, L. A. B. "Sugarcane Bioethanol: R\&D for productivity and sustainability", edited by Editora Edgard Blucher Ltda., 2010, pp. 994. ISBN-10: 8521205309.

Desouky, S. E. S.; Abdel-Rahman, M. A.; Azab, M. S.; Esmael, M. E. Batch and fed-batch production of polyhydroxyalkanoates from sugarcane molasses by Bacillus plexus Azu-A2. Journal of Innovation in Pharmaceutical and Biological Sciences, v. 4: 55-66, 2017.

Dias, M. O. S.; Junqueira, T. L.; Jesus, C. D. F.; Rossell, C. E. V.; Maciel-Filho, R.; Bonomi, A. Improving bioethanol production - Comparison between extractive and low temperature fermentation. Applied Energy, v. 98: 548-555, 2012. DOI:

10.1016/j.apenergy.2012.04.030. 
Dowd, M. K.; Johansen, S. L.; Cantarella, L. Low molecular weight organic composition of ethanol stillage from sugarcane molasses, citrus waste, and sweet whey. Journal of Agriculture and Food Chemistry, v. 42: 283-288, 1994. DOI: 10.1021/jf00038a011.

Eggleston, G.; Basso, L. C.; Amorim, H. V.; Paulillo, S. C. L.; Basso, T. O. Mannitol as a sensitive indicator of sugarcane deterioration and bacterial contamination in fuel alcohol production. Zuckerindustrie/Sugar Industry, v. 132: 33-39, 2007.

Esa, F.; Tarisin, S. M.; Rahman, N. A. Overview of bacterial cellulose production and application. Agriculture and Agricultural Science Procedia, v. 2: 113-119, 2014. DOI: 10.1016/j.aaspro.2014.11.017.

España-Gamboa, E.; Mijangos-Cortes, J.; Barahona-Perez, L.; Dominguez-Maldonado, J.; Hernández-Zarate, G.; Alzate-Gaviria, L. Vinasses: characterization and treatments.

Waste Management and Research, v. 1: 16, 2011. DOI: 10.1177/0734242X10387313.

España-Gamboa, E.; Mijangos-Cortes, J.; Hernández-Zarate, G.; Dominguez-Maldonado, J.; Alzate-Gaviria, L. Methane production by treating vinasses from hydrous ethanol using a modified UASB reactor. Biotechnology for Biofuels, v. 5: 82-90, 2012. DOI:

10.1186/1754-6834-5-82.

Ferreira, L. F. R.; Aguiar, M. M.; Messias, T. G.; Pompeu, G. B.; Lopez, A. M. Q.; Sila, D. P.; Monteiro, R. T. Evaluation of sugar-cane vinasse treated with Pleurotus sajor-caju utilizing aquatic organisms as toxicological indicators. Ecotoxicology and Environmental Safety, v. 74: 132-137, 2011. DOI: 10.1016/j.ecoenv.2010.08.042.

Jardine, J. G.; Dispato, I.; Peres, M. R. Considerações Sobre o Bioetanol Lignocelulósico para Subsidiar a Elaboração de Conteúdo da Árvore do Conhecimento Agroenergia. Access: https://ainfo.cnptia.embrapa.br/digital/bitstream/item/17345/1/doc95.pdf. 2009.

Julkunen-Tiitto, R. Phenolic Constituents in the Leaves of Northern Willows: Methods for the Analysis of Certain Phenolics. Journal of Agricultural and Food Chemistry, v. 33: 213-217, 1985. DOI: 10.1021/jf00062a013.

Kadier, A.; Simayi, Y.; Kalil, M. S.; Abdeshasian, P.; Hamid, A. A. A review of the substrates used in microbial electrolysis cells (MECs) for producing sustainable and clean hydrogen gas. Renewable Energy, v. 71: 466-472, 2014. DOI:

10.1016/j.renene.2014.05.052.

Khiyami, M. A.; Al-Fadual, S.; Bahklia, A. H. Polyhydroxyalkanoates production via Bacillus plastic composite support (PCS) biofilm and date palm syrup. Journal of Medicinal Plants Research, v. 5: 3312-3320, 2011.

Lopes, M. L.; Paulillo, S. C. L.; Godoy, A.; Cherubin, R. A.; Lorenzi, M. S.; Giometti, F. H. C. Ethanol production in Brazil: a bridge between science and industry. Brazilian Journal of Microbiology, v. 47: 64-76, 2016. DOI: 10.1016/j.bjm.2016.10.003.

López-López, A.; León-Becerril, E.; Rosales-Contreras, M. E.; Villegas-García, E. Influence of alkalinity and VFAs on the performance of an UASB reactor with recirculation for the treatment of Tequila vinasses. Environmental Technology, v. 36: 2468-2476, 2015. DOI: 10.1080/09593330.2015.1034790. 
Liu, L.; Duan, X.; Wu, J. L-Tryptophan production in Escherichia coli improved by weakening Pta-AckA pathway. PLoS ONE, v. 11: e0158200, 2016. DOI:

10.1371/journal.pone.0158200.

Lu, L.; Ren, N.; Xing, D.; Logan, B. E. Hydrogen production with effluent from an ethanol$\mathrm{H}_{2}$-coproducing fermentation reactor using a single chamber microbial electrolysis cell. Biosensors and Bioelectronics, v. 24: 3055-3060, 2009. DOI:

10.1016/j.bios.2009.03.024.

Macrelli, S.; Galbe, M.; Wallberg, O. Effects of production and market factors on ethanol profitability for an integrated first and second generation ethanol plant using the whole sugarcane as feedstock. Biotechnology for Biofuels, v. 7:26, 2014. DOI: 10.1186/17546834-7-26.

Md, F. Biosurfactant: Production and Application. Journal of Petroleum \& Environmental Biotechnology, v. 3: 4, 2012. DOI: 10.4172/2157-7463.1000124.

Medina, C. C.; Neves, C. S. V. J.; Fonseca, I. C. B.; Torreti, A. F. Crescimento radicular e produtividade de cana-de-açúcar em função de doses de vinhaça em fertirrigação.

Semina: Ciências Agrárias, v.23: 179-184, 2002. DOI: 10.5433/16790359.2002v23n2p179.

Metrohm. Metrosep Carb 2: Carbohydrate separation column for ion chromatography. Access:

https://partners.metrohm.com/GetDocument?action=get_dms_document\&docid=2405773. 2016

Metrohm. Fast IC: Separation of standard cations in five minutes, IC Application Note C151. Access: https://www.metrohm.com/en-ae/applications/\%7BD22BB24A-448D-4B18A82B-6AF45179057C\%7D?fromApplicationFinder=true. 2015a.

Metrohm. Determination of anions in tap water in accordance with US EPA Method 300. Access: https://www.metrohm.com/en/applications/\%7B1F9E1DD6-4846-411D-B6BAOFB23BAC20D6\%7D?fromApplicationFinder=true. 2015b.

Moraes, B. S.; Junqueira, T. L.; Pavanello, L. G.; Cavalett, O.; Mantelatto, P. E.; Bonomi, A.; Zaiat, M. Anaerobic digestion of vinasse from sugarcane biorefineries in Brazil from energy, environmental, and economic perspectives: Profit or expense? Applied Energy, v. 113: 825-835, 2014. DOI: 10.1016/j.apenergy.2013.07.018.

Moraes, B. S.; Petersen, S. O.; Zaiat, M.; Sommer, S. G.; Triolo, J. M. Reduction in greenhouse gas emissions from vinasse through anaerobic digestion. Applied Energy, v. 189: 21-30, 2017. DOI: 10.1016/j.apenergy.2016.12.009.

Moraes, B. S.; Zaiat, M.; Bonomi, A. Anaerobic digestion of vinasse from sugarcane ethanol production in Brazil: Challenges and perspectives. Renewable and Sustainable Energy Reviews, v. 44: 888-903, 2015. DOI: 10.1016/j.rser.2015.01.023. 
Nacheva, P. M.; Chávez, G. M.; Chacón, J. M.; Chuil, A. C. Treatment of sugarcane mill wastewater in an upflow anaerobic sludge bed reactor. Water Science and Technology, v. 60: 1347-1352, 2009. DOI: 10.2166/wst.2009.402.

Naspolini, B. F.; Machado, A. C. O.; Crav-Junior, W. B.; Freire, D. M. G.; Cammarota, M. C. Bioconversion of sugarcane vinasse into high-added value products and energy.

Biomed Research International, v. 2017, 8986165, 2017. DOI: 10.1155/2017/8986165.

Nevoigt, E.; Stahl, U. Osmoregulation and glycerol metabolism in the yeast

Saccharomyces cerevisiae. FEMS Microbiology Reviews, v. 21: 231-241, 1997. DOI: 10.1111/j.1574-6976.1997.tb00352.x.

Oliva-Neto, P. and Yokoya, F. Susceptibility of Saccharomyces cerevisiae and lactic acid bacteria from the alcohol industry to several antimicrobial compounds. Brazilian Journal of Microbiology, v. 32: 10-14, 2001. DOI: 10.1590/S1517-83822001000100003.

Oliveira, B. G.; Carvalho, J. L. N.; Cerri, C. E. P.; Cerri, C. C.; Feigl, B. Greenhouse gas emissions from sugarcane vinasse transportation by open channel: a case study in Brazil. Journal of Cleaner Production, v. 94: 102-107, 2015. DOI:

10.1016/j.jclepro.2015.02.025.

Ortiz-Muniz, B.; Carvajal-Zarrabal, O.; Torrestiana-Sanchez, B.; Aguilar-Uscanga, M. G. Kinetic study on ethanol production using Saccharomyces cerevisiae ITV-01 yeast isolated from sugar cane molasses. Journal of Chemical Technology and Biotechnology, v. 85: 1361-1367, 2010. DOI: 10.1002/jctb.2441.

Pathak, H.; Joshi, H. C.; Chaudhary, A.; Chaudhary, R.; Kalra, N.; Dwiwedi, M. K. Soil amendment with distillery effluent for wheat and rice cultivation. Water, Air and Soil Pollution, v. 113: 133-140, 1999. DOI: 10.1023/A:1005058321924.

Paulino, A.; Medina, C.; Robaina, C.; Laurani, R. Produções agrícola e industrial de canade-açúcar submetida a doses de vinhaça. Semina: Ciências Agrárias, v. 23: 145-150, 2002. DOI: 10.5433/1679-0359.2002v23n2p145.

Pedro-Escher, J.; Maziviero, G. T.; Fontanetti, C. S. Mutagenic action of sugarcane vinasse in the Tradescantia pallida Test System. Journal of Ecosystem \& Econography, v. $4: 2,2014$. DOI: 10.4172/2157-7625.1000145.

Penteado, E. D.; Lazaro, C. Z.; Sakamoto, I. K.; Zaiat, M. Influence of seed sludge and pretreatment method on hydrogen production in packed-bed anaerobic reactors.

International Journal oh Hydrogen Energy, v. 38: 6137-6145, 2013. DOI:

10.1016/j.ijhydene.2013.01.067.

Prado, E. A. F.; Vitorino, A. C. T.; Marchi, G.; Muniz, D. H. F.; Souza, T. A. Vinasse dynamics on soil solution under sugarcane crop: inorganic and organic ion analysis.

Water, Air, and Soil Pollution, v. 227: 145, 2016. DOI: 10.1007/s11270-016-2846-7.

Ratanapariyanuch, K.; Shen, J.; Jia, Y.; Tyler, R. T.; Shim, Y. Y.; Reaney, M. J. T. Rapid NMR method for the quantification of organic compounds in thin stillage. Journal of Agricultural and Food Chemistry, v. 59: 10454-10460, 2011. DOI: 10.1021/jf2026007. 
Rathika, R.; Janaki, V.; Shanthi, K.; Kamala-Kannan. S. Bioconversion of agro-industrial effluents for polyhydroxyalkanoates production using Bacillus subtilise RS1. International Journal of Environmental Science and Technology, v. 16: 5725-5734, 2018. DOI: 10.1007/s13762-018-2155-3.

Reis, C. M.; Carosia, M. F.; Sakamoto, I. K.; Varesche, M. B. A.; Silva, E. L. Evaluation of hydrogen and methane production from sugarcane vinasse in an anaerobic fluidized bed reactor. International Journal of Hydrogen Energy, v. 40: 8498-8509, 2015. DOI: 10.1016/j.jjhydene.2015.04.136.

Revin, V.; Liyaskina, E.; Nazarkina, M.; Bogatyreva, A.; Shchankin, M. Cost-effective production of bacterial cellulose using acidic food industry by-products. Brazilian Journal of Microbiology, v. 495: 151-159, 2018. DOI: 10.1016/j.bjm.2017.12.012.

Ribeiro, A. C.; Novais, R. F.; Bahia-Filho, A. F. C. Efeitos da vinhaça sobre a dispersão de argila de amostras de latossolos. Revista Ceres, v. 30 (167): 12-18, 1983.

Rittmann, D.; Lindner, S. N.; Wendisch, V. F. Engineering of a glycerol utilisation pathway for amino acid production by Corynebacterium glutamicum. Applied and Environmental Microbiology, v. 74: 6216-6222, 2008. DOI: 10.1128/AEM.00963-08.

Roncevic, Z. Z.; Bajic, B. Z.; Grahovac, J. A.; Dodic, S. N.; Dodic, J. M. Effect of the initial glycerol concentration in the medium on the xanthan biosynthesis. Acta Periodica Technologica, v. 45: 238-246, 2014. DOI: 10.2298/APT1445239R.

Sahu, O. Assessment of sugarcane industry: Suitability for production, consumption and utilisation. Annals of Agrarian Science, v. 16: 389-395, 2018. DOI:

10.1016/j.aasci.2018.08.001.

Santos, F. P.; Oliveira-Junior, A. M.; Nunes, T. P.; Silva, C. E. F.; Abud, A. K. S. Bioconversion of agro-industrial wastes into xanthan gum. Chemical Engineering Transaction, v. 49: 145-150, 2016. DOI: 10.3303/CET1649025.

Santos, G.A.; Rossiello, R. O. P.; Fernandes, M. S.; O’Grady, P. C. Efeitos da vinhaça sobre o $\mathrm{pH}$ do solo, a germinação e o acúmulo de potássio em milho. Pesquisa Agropecuária Brasileira, v. 16: 489-493 , 1981.

Silva, M. A. S.; Girebeler, N. P.; Borges, L. C. Uso de vinhaça e impactos nas propriedades do solo e lençol freático. Revista Brasileira de Engenharia Agrícola e Ambiental, v. 11: 108-114, 2007. DOI: 10.1590/S1415-43662007000100014.

Soto, M. A. A.; Basso, J. B.; Kiang, C. H.; Genuchten, M. T. Simulation of water flow and ion transport from vinasse in a transect of the Rio Claro formation. Águas Subterrâneas, v. 29: 162-174, 2015. DOI: 10.14295/ras.v29i2.28239.

Souza, J. K. C.; Mesquita, F.O.; Dantas-Neto. J.; Souza, M. M. A.; Farias, C. H. A.; Mendes, H.C.; Nunes, R. M. A. Fertirrigação com vinhaça na produção de cana-deaçúcar. Agropecuária Científica no Seminárida, v. 11: 7-12, 2015. 
Stams, A. J. M. Metabolic interactions between anaerobic bacteria in methanogenic environments. Antonie van Leeuwenhoek, v. 66: 271-294, 1994. DOI:

10.1007/BF00871644.

Stephen, J. D.; Mabee, W.E.; Saddler, J. N. Will second-generation ethanol be able to compete with first-generation ethanol? Opportunities for cost reduction. Biofuels, Bioproducs and Biorefinering. v. 6: 159-176, 2012. DOI:10.1002/bbb.331.

Sydney, E. B. Valorization of vinasse as broth for biological hydrogen and volatile fatty acids production by means of anaerobic bacteria. Other. Université Blaise Pascal Clermont-Ferrnd II, 2013. English.

UNICA. Balanço de Atividades 2012/13 a 2018/19. Acesso: https://unica.com.br/wpcontent/uploads/2019/06/Relatorio-Atividades-201213-a-201819.pdf. 2019a.

UNICA. Moagem de cana-de-açúcar e produção de açúcar e etanol. Access:

http://www.unicadata.com.br/pdfHPM.php?idioma=1\&tipoHistorico=4\&idTabela=1984\&pro duto $=\&$ safra $=2017 / 2018 \&$ safralni=\&safraFim $=\&$ estado $=R S, S C, P R, S P, R J, M G, E S, M S, M T$, GO,DF,BA,SE,AL,PE,PB,RN,CE,PI,MA,TO,PA. $2019 \mathrm{~b}$.

UNICA. Etanol total - 1980/1981 até 2017/2018. Access:

http://www.unicadata.com.br/historico-de-producao-e-

moagem.php?idMn=31\&tipoHistorico $=2 \&$ acao $=$ visualizar\&idTabela $=2316 \&$ produto=etanol total\&safralni=1980\%2F1981\&safraFim $=2017 \% 2 F 2018 \&$ estado=RS\%2CSC $\% 2 C P R \% 2 C$ SP\%2CRJ\%2CMG\%2CES\%2CMS\%2CMT\%2CGO\%2CDF\%2CBA\%2CSE\%2CAL\%2CP E\%2CPB\%2CRN\%2CCE\%2CPI\%2CMA\%2CTO\%2CPA\%2CAP\%2CRO\%2CAM\%2CAC $\% 2 C R R .2020$.

U.S. Energy Information Administration. Data on U.S. fuel ethanol production, imports, exports and consumption. Access: https://www.eia.gov/tools/faqs/faq. php?id=90\&t=4. 2019.

Ying, H.; He. X.; Li. Y.; Chen. K.; Ouyang, P. Optimization of culture conditions for enhanced lysine production using engineered Escherichia coli. Applied Biochemistry and Biotechnology, v. 172: 3835-3843, 2014. DOI: 10.1007/s12010-014-0820-7. 


\section{RESUMO}

O Brasil é o segundo maior produtor de etanol e os resíduos gerados pela fermentação alcoólica têm levantado questões econômicas e ambientais. Recentemente a indústria brasileira implantou o processo de segunda geração (2G) para atender às crescentes demandas pelo biocombustível. Neste estudo, foi investigado se a vinhaça $2 \mathrm{G}$ tem potencial para trazer os mesmos desafios ambientais associados à vinhaça de primeira geração (1G), isto é, aquela proveniente dos processos de etanol a partir de caldo e/ou melaço de canade-açúcar. Foi coletada vinhaça de uma das unidades de etanol $2 \mathrm{G}$ recentemente instaladas no Estado de São Paulo e, então, caracterizada quimicamente. Considerandose glicerol, manitol, açúcares residuais e ácidos orgânicos, determinou-se que a vinhaça $2 \mathrm{G}$ possui um total de fonte de carbono de $23.050 \mathrm{mg} \mathrm{L}-1$ (comparado a $4.800 \mathrm{mg} \mathrm{L}-1$ na vinhaça $1 \mathrm{G}$ ). Magnésio, cálcio, potássio e outros sais também foram determinados. Com base na composição química, vinhaças podem ser consideradas fontes de nutrientes para bioprocessos. Finalmente, foram abordados bioprocessos cujas demandas nutricionais podem ser completa ou parcialmente garantidas pelas vinhaças, resultando na produção de bioenergia ou bioprodutos.

Palavras-chave: Setor sucroenergético. Análises cromatográficas. Valorização de resíduos. Biorrefinarias. Vinhaça 2G.

\section{RESUMEN}

Brasil es el segundo más grande productor de etanol y los residuos generados por la fermentación alcohólica han levantado cuestiones económicas y ambientales. Recientemente la industria brasileña implanto el proceso de segunda generación (2G) para atender a las crecientes demandas por el biocombustible. En este estudio, fue investigado se la vinaza $2 \mathrm{G}$ tiene potencial para traer los mismos desafíos ambientales asociados a la vinaza de primera generación (1G), aquella proveniente de los procesos de etanol a partir de caldo y/o melaza de caña de azúcar. Fue colectada vinaza de una de las unidades de etanol 2G recientemente instaladas en el Estado de São Paulo y, así, caracterizada químicamente. Considerándose glicerol, manitol, azúcares residuales y ácidos orgánicos, se determinó que la vinaza $2 \mathrm{G}$ posee un total de fuente de carbono de $23.050 \mathrm{mg} \mathrm{L}^{-1}$ (comparado a $4.800 \mathrm{mg} \mathrm{L}^{-1}$ en la vinaza $1 \mathrm{G}$ ). Magnesio, calcio, potasio y otras sales también se determinaron. Con base en la composición química, vinazas pueden ser consideradas fuentes de nutrientes para bio-procesos. Finalmente se abordaron bio-procesos cuyas demandas nutricionales pueden ser completa o parcialmente garantidas por las vinazas, resultando en la producción de bioenergía o bio-productos.

Palabras clave: Sector sucroenergético. Análisis cromatográficas. Valorización de residuos. Biorrefinerías. Vinaza $2 \mathrm{G}$. 


\section{LICENÇA DE USO}

Este é um artigo publicado em acesso aberto (Open Access) sob a licença Creative Commons Atribuição 4.0 Internacional (CC BY 4.0), que permite uso, distribuição e reprodução em qualquer meio, desde que o trabalho original seja corretamente citado. Mais informações em: http://creativecommons.org/licenses/by/4.0

\section{CONFLITO DE INTERESSES}

Os autores declaram que não há conflito de interesses neste trabalho.

\section{CONTRIBUIÇÕES AUTORAIS}

Manuella Souza Silverio: Conceptualization; Laboratorial execution; Data analysis; Writing - original draft preparation.

Rubens Perez Calegari: Conceptualization; Data analysis; Writing - review and editing.

Gabriela Maria Ferreira Lima Leite: Laboratorial execution.

Laysa Maciel Lewandowski Meira Prado: Laboratorial execution.

Bianca Chaves Martins: Laboratorial execution.

Eric Alberto da Silva: Laboratorial execution.

José Piotrovski Neto: Resources; Funding.

André Gomig: Resources; Funding.

Antonio Sampaio Baptista: Conceptualization; Methodology; Writing - review and editing; Resources.

\section{FINANCIAMENTO}

This study was financed by Engie Brasil Energia S.A. and by the Coordenação de Aperfeiçoamento de Pessoal de Nível Superior - Brasil (CAPES), Finance Code 001.

\section{COMO REFERENCIAR}

SILVERIO, Manuella Souza; CALEGARI, Rubens Perez; LEITE, Gabriela Maria Ferreira Lima; PRADO, Laysa Maciel Lewandowski Meira; MARTINS, Bianca Chaves; da SILVA, Eric Alberto; NETO, José Piotrovski; GOMIG, André; BAPTISTA, Antonio Sampaio. Vinasse from the brazilian lignocellulosic ethanol process: chemical composition and potential for bioprocesses. Revista Brasileira de Engenharia de Biossistemas (Tupã), v. 15, n.1, p. 42-68, 2021. DOI: http://dx.doi.org/10.18011/bioeng2021v15n1p42-68.

\section{RESPONSABILIBADE EDITORIAL}

Prof. Dr. Fernando Ferrari Putti ${ }^{1}$, Prof. Dr. Paulo Sérgio Barbosa dos Santos ${ }^{1}$, Prof. Dr. Eduardo Festozo Vicente ${ }^{1}$ e Prof. Dr. Diogo de Lucca Sartori ${ }^{1}$

1 Universidade Estadual Paulista "Júlio de Mesquita Filho", FCE - Faculdade de Ciências e Engenharia, Tupã, SP, Brasil. 